\title{
Współpraca touroperatorów z pozalotniczymi przewoźnikami pasażerskimi w Polsce
}

\author{
Cooperation of tour operators with non-air passenger carriers in Poland
}

\section{ZBIGNIEW TAYLOR, ARIEL CIECHAŃSKI}

Instytut Geografii i Przestrzennego Zagospodarowania im. S. Leszczyckiego PAN, 00-818 Warszawa, ul. Twarda 51/55; z.taylor@twarda.pan.pl ariel@twarda.pan.pl

Zarys treści. Poza transportem lotniczym (patrz: Taylor i Ciechański, 2015a, b), w obsłudze zorganizowanego ruchu turystycznego w Polsce, ważną rolę odgrywa transport samochodowy. W artykule przedstawia się największych przewoźników drogowych, w tym firmy wykonujące połączenia „antenowe” i w miejscu destynacji, a ponadto pozostałych przewoźników obsługujących polskich touroperatorów (statki wycieczkowe, promy, koleje). Rola tych przewoźników w polskiej turystyce jest jednak niewielka w porównaniu z przewoźnikami lotniczymi i autokarowymi ${ }^{1}$.

Słowa kluczowe: przewoźnicy drogowi, statki wycieczkowe, promy, koleje, turystyka zorganizowana, touroperatorzy, Polska.

\section{Wstęp}

Literatura na temat pozalotniczych przewoźników w obsłudze ruchu turystycznego jest znacznie skromniejsza niż w przypadku transportu lotniczego. Stosunkowo bogate jest piśmiennictwo poświęcone morskim rejsom turystycznym. Na przykład, B. Dickinson i A. Vladimir (2008) badają różne aspekty współczesnej żeglugi morskiej, opisują rewolucyjne zmiany zarządzania, marketing i techniki sprzedaży, wszystko pod wiele mówiącym tytułem Selling the Sea. Turystyka statkami wycieczkowymi widziana z rozmaitych perspektyw (popyt na statki wycieczkowe; destynacje i produkty; wpływy gospodarcze, społeczne i środowiskowe, etc.) jest z kolei tematem pracy zbiorowej pod redakcją R.K. Dowlinga (2006). Również światowe szlaki żeglugowe są rozpatrywane w literaturze (np. Cornell, 2008). Z kolei A. Panasiuk i M. Pluciński (2008) analizują żeglugę bli-

\footnotetext{
1 Artykuł powstał w wyniku realizacji projektu NCN nr 2011/01/B/HS4/00837. Jest częścią większego opracowania (Taylor i Ciechański, 2014a). 
skiego zasięgu w obsłudze ruchu pasażerskiego. Wspólną cechą wszystkich tych publikacji jest ich bardzo praktyczny charakter.

Ciekawą pracę nt. turystyki kolejowej w Polsce publikuje F. Bebenow (2015) wskazując na problemy, ograniczenia, lecz także możliwości jej rozwoju. R. Gawek (2000) skupia się warunkach współpracy przewoźników kolejowych z rynkiem turystycznym. Jak dotychczas, najpowszechniej występującą formą odpowiedzi na potrzeby turystów jest udostępnianie zabytkowych obiektów kolejowych zwiedzającym (Halsall, 2001; Załuska, 2010; Lewandowski, 2013), natomiast wykorzystanie kolei jako środka transportu często wiąże się z koniecznością rewitalizacji linii.

Odrębnym zagadnieniem jest współdziałanie przewoźników lotniczych i kolejowych, czym zajmują się m.in. M. Givoni i D. Banister (2006) oraz P. Chiambaretto i Ch. Decker (2012).

Stosunkowo uboższa jest literatura poświęcona transportowi autokarowemu - zupełnie nie odpowiada ona roli jaką ten środek transportu odgrywa w światowej turystyce. Niemniej, można w niej znaleźć pogłębione analizy charakteryzujące podróże autokarowe, uwzględniające potencjalne różnice kulturowe w zależności od kraju pochodzenia turystów (np. Becken, 2005).

Autokar jest drugim co do częstości wykorzystywania przez 38 największych polskich touroperatorów (Taylor i Ciechański, 2014b) środkiem transportu. Korzysta z niego 15,79\% badanych touroperatorów, imprezy autokarowe przynoszą 3,2\% obrotów, a uczestniczy w nich 8,62\% klientów biur podróży (Taylor i Ciechański, 2014a). W rzeczywistości udział autokaru jest jednak większy, gdyż autokar jest najczęstszym obok samolotu środkiem transportu, uwzględnionym w kategorii „różne środki” transportu.

Jeszcze częściej był on wykorzystywany w latach 1990., ale wraz ze wzrostem zamożności społeczeństwa, a także częściową zmianą charakteru turystyki wyjazdowej - z wycieczek objazdowych (zwiedzania) na typowo wypoczynkowe, jego udział w podróżach zmalał. Autokar pozwala na uniknięcie problemów transferu, bagażu, załatwiania formalności podróżnych, znajomości języków obcych. „Podróże autokarowe są też na ogół tańsze od lotniczych, a często również kolejowych. Ze względu na wymienione zalety autokar stał się środkiem transportu szczególnie chętnie wybieranym w niektórych segmentach popytu turystycznego" (Konieczna-Domańska, 2008, s. 61). Autokary wykorzystywane są przede wszystkim w bliższych relacjach, szczególnie przy wyjazdach narciarskich (np. w Alpy, Dolomity), a częściowo również podczas wycieczek objazdowych (Europa Środkowo-Wschodnia, Europa Południowa). 


\section{Najwięksi przewoźnicy drogowi obsługujący polskich touroperatorów}

Dane dotyczące przewoźników drogowych i współpracujących z nimi touroperatorów są trudniej dostępne niż w przypadku przewoźników lotniczych. Nasi przewoźnicy drogowi są najczęściej firmami małymi, jedno- lub kilkuosobowymi, posiadającymi czasem jeden autokar, których nie łączą z touroperatorami stałe umowy o współpracy.

Autorska baza obejmuje największych polskich przewoźników drogowych realizujących tzw. przewozy „antenowe” (4 podmioty) i autokarowe (7 podmiotów) na rzecz polskich touroperatorów. Częściowo biura podróży dysponują własnym parkiem autokarowym. Baza powstała głównie na podstawie katalogów i stron internetowych touroperatorów. Podobnie jak w przypadku linii lotniczych, informacje dotyczące przewoźników autokarowych zostały uzupełnione na podstawie danych firmy InfoVeriti (www.infoveriti.pl), materiałów prasowych, stron internetowych i raportów rocznych poszczególnych przedsiębiorstw, według stanu na 31.12.2012 r. Ostatecznie baza przewoźników autokarowych zawiera następujące informacje: nazwę przewoźnika, jego siedzibę, rodzaj działalności, formę własności i prawną, rok rozpoczęcia działalności w Polsce, liczbę i nazwy współpracujących touroperatorów, obroty (ogółem), wielkość zatrudnienia (ogółem), rodzaj środków transportu, tabor (ogółem) i kraj pochodzenia kapitału.

Tabela 1 zawiera informacje o 11 największych przewoźnikach autokarowych, wykonujących przewozy na rzecz polskich touroperatorów, a których roczne obroty wynoszą nie mniej niż $2 \mathrm{mln}$ zł. Największym przewoźnikiem autokarowym jest Prywatne Biuro Podróży Sindbad, które obok regularnych międzynarodowych przewozów autokarowych zajmuje się turystyką wyjazdową i przyjazdową, a także wynajmem autokarów (m.in. firmie Lekier). Touroperatorstwo jest w tym przypadku działalnością poboczną, o czym świadczą obroty 1,52 mln przy 158,03 mln obrotów całkowitych. Również wielkość zatrudnienia (405) oraz flota własna (95 autokarów) i dzierżawiona (21), stawiają Sindbad na wyjątkowej pozycji. Pozostałych 10 przewoźników autokarowych dysponuje zdecydowanie mniejszą flotą, zatrudnia mniej pracowników, pomimo że niektórzy z nich prowadzą dość szeroki profil działalności.

Niektórzy przewoźnicy ograniczają się do wynajmu autokarów (np. Bomatur, Trans Bis, Delta Travel Transport), inni ponadto organizują własne imprezy turystyczne (BUT Żak Tourist, Hubertus), prowadzą rozkładowe przewozy autokarowe (Żak Express, BP Tour, Podlasie Express) lub obsługują transfery na lotniska, nawet zagraniczne (SBS Eurotransport). Jak widać, część przewoźników autokarowych świadczących usługi na rzecz największych polskich touroperatorów wykonuje także usługi turystyczne pod własnym szyldem, zarówno 
pośrednicząc w sprzedaży cudzych imprez, jak organizując własne (np. wycieczki szkolne, zakładowe).

Wszyscy przewoźnicy drogowi są firmami prywatnymi, a jeśli chodzi o formy prawne najczęściej są własnością osób fizycznych (Sindbad, BP Tour, Hubertus, SBS Eurotransport) lub spółkami z ograniczoną odpowiedzialnością (BUT Żak Tourist, Tramp, Delta Travel Transport, Podlasie Express). Tylko niektóre są spółkami jawnymi (Bomatur) i spółkami cywilnymi (Trans Bis). Nawet firmy o kapitale pochodzącym od osób fizycznych, dysponują jednak stosunkowo rozbudowanym parkiem pojazdów, często tworzonym przez wiele lat.

Przewoźnicy zatrudniają od 10 do 30 pracowników (wyjątkiem jest wspomniany wyżej Sindbad), a flota składa się od kilku do 40 jednostek (znów z wyjątkiem Sindbada). Część przewoźników autokarowych współpracuje na stałe z wybranymi touropearatorami, ale jest to raczej mniejszość, o czym już wspominano. Siedziby największych przewoźników autokarowych rozrzucone są po Polsce, z nieco większą koncentracją w południowej części kraju. W przypadku touroperatorów krakowskich obserwuje się wykorzystywanie autokarów miejscowych przewoźników.

\section{Touroperatorzy dysponujący własnym i wynajmowanym taborem autokarowym}

Brakuje precyzyjnych informacji na temat współpracy polskich touroperatorów z konkretnymi przewoźnikami autobusowymi. Tylko kilku touroperatorów podaje takie informacje na swoich stronach internetowych. Może to wskazywać na brak długoterminowych porozumień o współpracy i dobieranie przewoźników ad hoc, w zależności od bieżących potrzeb.

Część badanych touroperatorów dysponuje własnym parkiem autokarowym, którym realizuje przewozy klientów własnych i ewentualnie konkurencji. I tak, do wykorzystania wyłącznie własnych autokarów ograniczają się np. Jan Pol Incoming Tour Operator, Mazurkas Travel, Funclub, Atas, Skarpa Travel. W dużej mierze są to touroperatorzy zajmujący się turystyką przyjazdową, którzy posiadają własny park autokarowy. Co więcej, własna flota autokarów charakterystyczna jest głównie dla touroperatorów z wyłącznym kapitałem polskim. Najwięksi touroperatorzy z kapitałem obcym (m.in. TUI Poland, Wezyr Holidays, Neckermann Polska, Sun \& Fun Holidays, Oasis Tours) i mieszanym polsko-zagranicznym (np. Viva Club Polska, Best Reisen Group) z reguły nie mają własnego parku autokarowego, natomiast w swojej ofercie zamieszczają imprezy (np. narciarskie, typowo wypoczynkowe) z dojazdem własnym.

Niektórzy touroperatorzy dysponują własnym parkiem autokarowym (np. Itaka, Rainbow Tours, Centrum Turystyki Oskar, Almatur Opole, Lekier, Sigma Travel), ale wykorzystują również wynajmowane cudze autokary. Tym samym starają się zachować pewną elastyczność, umożliwiającą właściwą reakcję na zmiany popytu na przewozy autokarowe, bez konieczności utrzymywania dużej floty. 
Tabela 1. Najwięksi przewoźnicy drogowi obsługujący polskich touroperatorów (stan na koniec 2012 r.)

The largest road carriers servicing Polish tour operators (as of 31 December 2012)

\begin{tabular}{|c|c|c|c|c|c|c|c|c|c|}
\hline $\begin{array}{l}\text { Przewoźnik } \\
\text { Carrier }\end{array}$ & $\begin{array}{l}\text { Siedziba } \\
\text { Seat in } \\
\text { Poland }\end{array}$ & $\begin{array}{l}\text { Rodzaj działalności } \\
\text { Type of activity }\end{array}$ & $\begin{array}{l}\text { Forma własno- } \\
\text { śi/prawna } \\
\text { Ownership/ } \\
\text { legal form }\end{array}$ & $\begin{array}{l}\text { Rok rozpo- } \\
\text { częcia dzia- } \\
\text { łalności } \\
\text { Year of esta- } \\
\text { blishment }\end{array}$ & $\begin{array}{c}\text { Obroty } \\
\text { (mln zł) } \\
\text { Turnover } \\
\text { (M zloties) }\end{array}$ & $\begin{array}{l}\text { Liczba } \\
\text { zatrudnionych } \\
\text { Number of } \\
\text { employees }\end{array}$ & $\begin{array}{l}\text { Wykorzystywane } \\
\text { środki transportu } \\
\text { Transport means } \\
\text { used }\end{array}$ & $\begin{array}{l}\text { Flota (ogółem) } \\
\text { Fleet (total) }\end{array}$ & $\begin{array}{l}\text { Obsługiwane biura } \\
\text { podróży w Polsce } \\
\text { Tour operators in } \\
\text { Poland served }\end{array}$ \\
\hline $\begin{array}{l}\text { Prywatne Biuro } \\
\text { Podróży Sindbad }\end{array}$ & Opole & $\begin{array}{l}\text { regularne międzynarodowe prze- } \\
\text { wozy autokarowe, turystyka wyjaz- } \\
\text { dowa i przyjazdowa, wynajem } \\
\text { autokarów }\end{array}$ & $\begin{array}{l}\text { prywatna/ } \\
\text { osoba fizyczna }\end{array}$ & 1983 & $158,03^{\mathrm{a}}$ & 405 & autokary & $\begin{array}{l}95+21 \\
\text { (dzierżawa) }\end{array}$ & Lekier \\
\hline Bomatur & $\begin{array}{l}\text { Czechowice- } \\
\text { Dziedzice }\end{array}$ & wynajem autokarów & $\begin{array}{l}\text { prywatna/ } \\
\text { spółka jawna }\end{array}$ & 2006 & 18,39 & 11 & autokary & 40 & Rainbow Tours \\
\hline BUT Żak Tourist & Augustów & $\begin{array}{l}\text { organizacja imprez turystycznych, } \\
\text { wynajem autokarów, rozkładowe } \\
\text { przewozy autokarowe }\end{array}$ & $\begin{array}{l}\text { prywatna/ } \\
\text { spółka z o.o. }\end{array}$ & 1998 & 2,83 & 30 & $\begin{array}{l}\text { autokary, mikro- } \\
\text { busy }\end{array}$ & $\begin{array}{l}22 \text { autokary, } \\
6 \text { mikrobusów }\end{array}$ & $\begin{array}{l}\text { połączenia antenowe } \\
\text { autokarami rejsowymi } \\
\text { dla Itaka }\end{array}$ \\
\hline BP Tourb & Bełżyce & $\begin{array}{l}\text { wynajem autokarów, rozkładowe } \\
\text { przewozy autokarowe }\end{array}$ & $\begin{array}{l}\text { prywatna/ } \\
\text { osoba fizyczna }\end{array}$ & 2002 & 5,0 & 30 & $\begin{array}{l}\text { autokary, mikro- } \\
\text { busy }\end{array}$ & $\begin{array}{l}13 \text { autokarów, } \\
14 \text { mikrobusów }\end{array}$ & $\begin{array}{l}\text { połączenia antenowe } \\
\text { dla Itaka }\end{array}$ \\
\hline Tramp & $\begin{array}{l}\text { Czechowice- } \\
\text { Dziedzice }\end{array}$ & $\begin{array}{l}\text { rozkładowe przewozy autokarowe, } \\
\text { wynajem autokarów }\end{array}$ & $\begin{array}{l}\text { prywatna/ } \\
\text { spółka z o.o. }\end{array}$ & 2004 & 5,03 & 19 & autokary & 16 & $\begin{array}{l}\text { Itaka, Rainbow Tours, } \\
\text { Omnia, Comfort } \\
\text { Lines, Eurolines, } \\
\text { Tramp-Travel }\end{array}$ \\
\hline $\begin{array}{l}\text { Przedsiębiorstwo } \\
\text { Transportowo- } \\
\text { Spedycyjne Trans } \\
\text { Bis }\end{array}$ & Myszków & wynajem autokarów & $\begin{array}{l}\text { prywatna/ } \\
\text { spółka cywilna }\end{array}$ & 1998 & 2,5 & 20 & autokary & 13 & $\begin{array}{l}\text { Rainbow Tours, BP } \\
\text { Olimp, Jafsport, Espa- } \\
\text { ce Trans, Euro Ray } \\
\text { Incoming }\end{array}$ \\
\hline $\begin{array}{l}\text { Turystyczny Prze- } \\
\text { wóz Osób Stani- } \\
\text { sław Pastuszak }\end{array}$ & Kraków & wynajem autokarów & $\begin{array}{l}\text { prywatna/ } \\
\text { osoba fizyczna }\end{array}$ & 1998 & 2,5 & 20 & $\begin{array}{l}\text { autokary, mikro- } \\
\text { busy }\end{array}$ & $\begin{array}{l}11 \text { autokarów, } \\
2 \text { mikrobusy }\end{array}$ & $\begin{array}{l}\text { Ecco Holiday, Jan Pol } \\
\text { Incoming, GTI Travel } \\
\text { Polska, BP Olimp, } \\
\text { Daasab Travel }\end{array}$ \\
\hline $\begin{array}{l}\text { Delta Travel } \\
\text { Transport }\end{array}$ & Kraków & wynajem autokarów & $\begin{array}{l}\text { prywatna/ } \\
\text { spółka z o.o. }\end{array}$ & 2007 & 3,53 & 10 & autokary & 7 & $\begin{array}{l}\text { CT Poland, Jan Pol } \\
\text { Incoming, Solo Tours, } \\
\text { Intercarc, Delta Travel }\end{array}$ \\
\hline $\begin{array}{l}\text { Hubertus Biuro } \\
\text { Usług Turystycz- } \\
\text { nych Tomasz } \\
\text { Widziński }\end{array}$ & Wągrowiec & $\begin{array}{l}\text { organizacja i sprzedaż agencyjna } \\
\text { imprez turystycznych, wynajem } \\
\text { autokarów }\end{array}$ & $\begin{array}{l}\text { prywatna/ } \\
\text { osoba fizyczna }\end{array}$ & 1991 & 2,0 & 10 & autokary & $\begin{array}{l}5 \text { autokarów, } \\
1 \text { mikrobus }\end{array}$ & Itaka \\
\hline Podlasie Express & Białystok & rozkładowe przewozy autokarowe & $\begin{array}{l}\text { prywatna/ } \\
\text { spółka z o.o. }\end{array}$ & 2004 & $\begin{array}{l}\text { brak } \\
\text { danych }\end{array}$ & brak danych & $\begin{array}{l}\text { autokary, mikro- } \\
\text { busy }\end{array}$ & brak danych & $\begin{array}{l}\text { połączenia antenowe } \\
\text { dla Itaka }\end{array}$ \\
\hline $\begin{array}{l}\text { Przedsiębiorstwo } \\
\text { Przewozów Pasa- } \\
\text { żerskich SBS } \\
\text { Eurotransport } \\
\text { Wojciech Jerzy } \\
\text { Deptalski }\end{array}$ & Szczecin & $\begin{array}{l}\text { transfery na lotnisko w Berlinie, } \\
\text { wynajem mikrobusów }\end{array}$ & $\begin{array}{l}\text { prywatna/ } \\
\text { osoba fizyczna }\end{array}$ & 2005 & $\begin{array}{l}\text { brak } \\
\text { danych }\end{array}$ & brak danych & mikrobusy & brak danych & Atas \\
\hline
\end{tabular}

${ }^{\mathrm{a}} \mathrm{w}$ tym $1,52 \mathrm{mln}$ zł obroty z touroperatorstwa.

b pełna nazwa: BP Tour Przedsiębiorstwo Wielobranżowe Piotr Brewczak.

Opracowanie własne, głównie na podstawie: (1) katalogów i stron internetowych touroperatorów; (2) stron internetowych przewoźników; (3) www.infoveriti.pl. Authors' own elaboration, mainly on the basis of: (1) catalogues and websites of tour operators; (2) websites of carriers; (3) www.infoveriti.pl. 
W przypadku grup przedsiębiorstw, takich jak Almatur, odnotowuje się wykorzystywanie przez touroperatorów nieposiadających własnego parku autokarów pojazdów innych podmiotów tej samej grupy. Na przykład, Almatur Polska wykorzystuje m.in. autokary Almatur Opole i Almatur Częstochowa.

\section{Przewoźnicy obsługujący połączenia „antenowe” i w miejscu destynacji}

Ze względu na rosnącą konkurencję i chęć lepszej penetracji przestrzennej rynku, niektórzy touroperatorzy wprowadzają tzw. połączenia „antenowe”. W zamyśle mają one służyć umożliwieniu dojazdu turystom zamieszkującym mniejsze miejscowości, położone z dala od największych ośrodków miejskich, do dowozu do punktów zbornych, którymi są większe miejscowości i/lub lotniska. Dysponujemy szczegółowymi informacjami na temat połączeń „antenowych” wykonywanych na rzecz trzech touroperatorów: Itaka, Rainbow Tours i Centrum Turystyki Oskar.

Największy touroperator Itaka do dowozu turystów do punktów zbornych wykorzystuje rejsowe prywatne autokary. Turyści wyjeżdżający z Lublina, Radomia i Kielc dowożeni są do Krakowa mikrobusami i autobusami firmy BP Tour. W podobny sposób, turyści z północno-wschodniej Polski (aż po Suwałki) dowożeni są do Warszawy pojazdami firmy Żak Express. Klienci z Białegostoku dowożeni są do Portu Lotniczego im. F. Chopina mikrobusami i autokarami przewoźnika Podlasie Express. Po zakończeniu imprezy, turyści są odwożeni do miejsc początkowych. Z kolei główne trasy obsługuje sama Itaka (ryc. 1). Turyści moga rozpoczynać i kończyć swoje imprezy w miastach położonych na trasach i w miejscowościach granicznych. W ten sposób, Itaka penetruje znaczną część obszaru Polski. Natomiast same imprezy wykonywane są autokarami własnymi i wypożyczanymi z firm Hubertus z Wągrowca i Tramp z Czechowic-Dziedzic.

Rainbow Tours praktycznie penetruje obszar całej Polski, przy czym większość połączeń jest obsługiwana przez flotę własną i współpracujących przewoźników - m.in. firm Transbis z Myszkowa i Bomatur z Czechowic-Dziedzic. Przewozy mają charakter zorganizowany i odbywają się według rozkładu jazdy. Uczestnicy imprez w punktach przesiadkowych są przesadzani do pojazdów kontynuujących jazdę do miejsc docelowych lub dowożeni do lotnisk. Trasy podstawowe są uzupełnione połączeniami „antenowymi” (ryc. 2). Dojazdy do miejsc przesiadkowych realizowane są nie tylko autokarami, ale również mikrobusami i samochodami osobowymi.

Centrum Turystyki Oskar jest średniej wielkości touroperatorem, dysponującym 9 autokarami. Głównie własnymi autokarami obsługuje linie prowadzące z Poznania i Warszawy na południe i południowy zachód Europy (przede wszystkim do Chorwacji, Grecji i Bułgarii). Ma mocno rozbudowaną sieć połączeń „antenowych”, która nie obejmuje jednak wschodniej Polski, z wyjątkiem Lublina. 


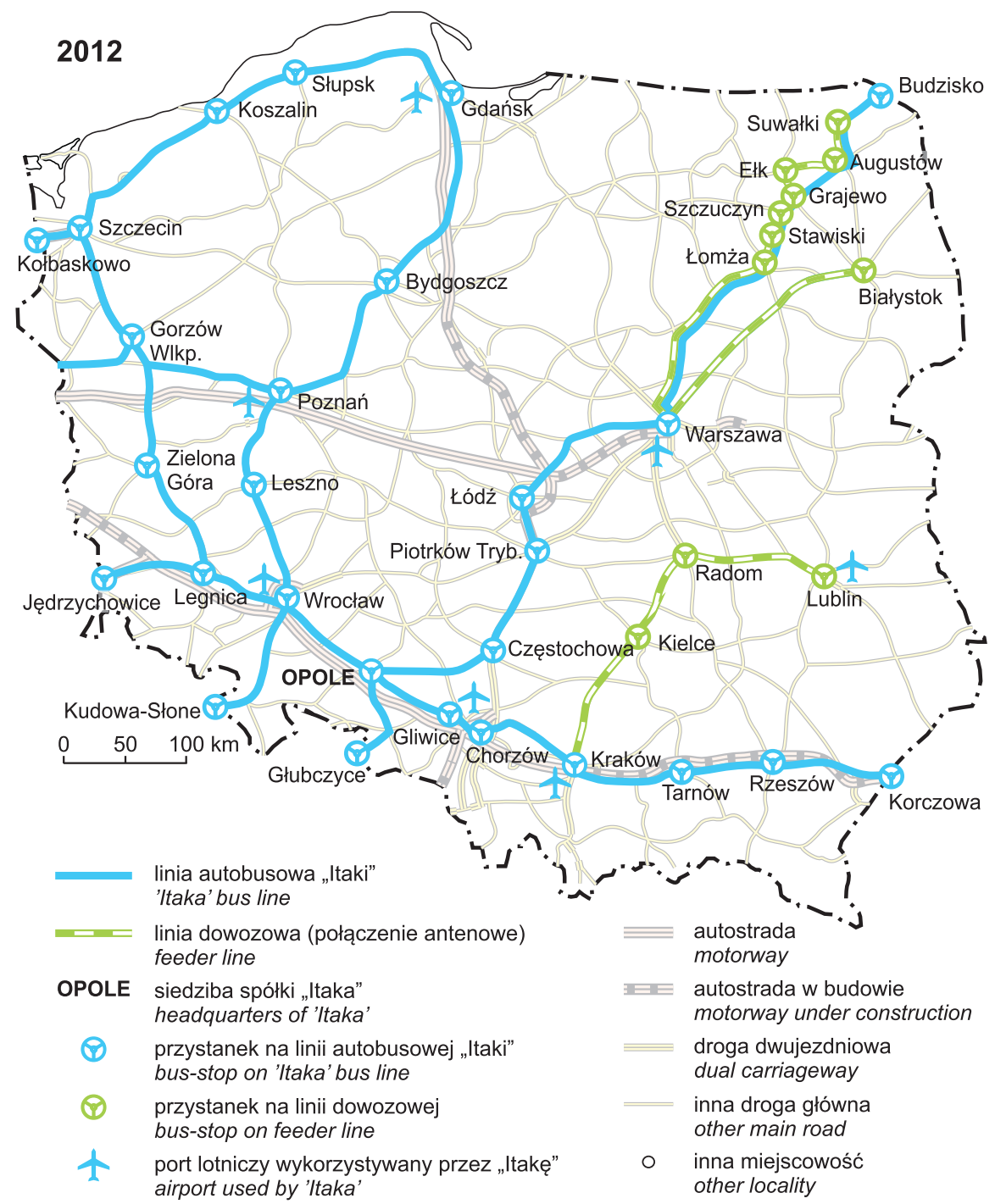

Ryc. 1. Sieć połączeń autobusowych i lotniska obsługujące wycieczki Itaki

The network of coach connections and airports servicing Itaka tours Opracowanie własne/Authors' own elaboration.

W miejscu destynacji touroperatorzy korzystają z usług lokalnych przewoźników, przede wszystkim w dwóch celach: (1) do transferów z lotnisk do hoteli; oraz (2) do obsługi fakultatywnych wycieczek przygotowanych w kooperacji z lokalnymi biurami podróży. W każdym kraju wygląda to inaczej: czasem jest 


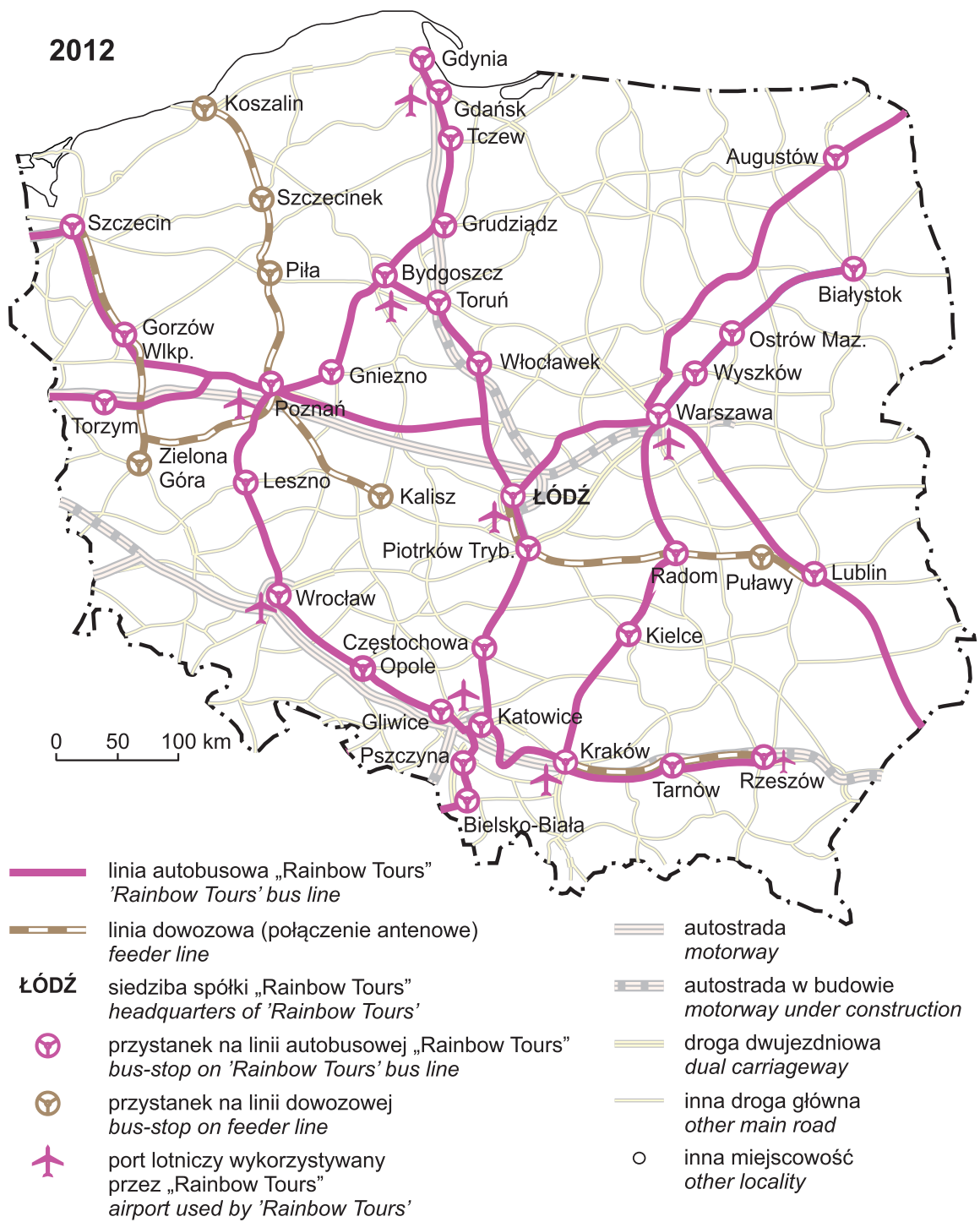

Ryc. 2. Sieć połączeń autobusowych i lotniska obsługujące wycieczki Rainbow Tours The network of coach connections and airports servicing Rainbow Tours Opracowanie własne/Authors' own elaboration.

to oddział międzynarodowego koncernu, a częściej lokalne biuro podróży. Jeśli wycieczka realizowana jest w całości autokarem wiozącym turystów z Polski, wtedy służy on również do przemieszczeń w obrębie destynacji. 
Obszerniejszą charakterystykę pięciu najważniejszych przewoźników drogowych zawiera praca Z. Taylora i A. Ciechańskiego (2014a). Są wśród nich firmy „wielobranżowe” i wyspecjalizowane, zajmujące się wyłącznie przewozami turystycznymi na rzecz polskich touroperatorów.

\section{Pozostali przewoźnicy obsługujący polskich touroperatorów}

Pozostałe środki transportu wykorzystywane są przez największych 38 touroperatorów raczej sporadycznie. Tylko niektórzy z nich informują o korzystaniu z innych niż samolot i/lub autokar środków transportu w organizowanych imprezach turystycznych.

\section{Statki wycieczkowe, promy}

Chociaż globalna rola rejsów wycieczkowych jest jeszcze relatywnie niewielka (2,1\% turystów bierze udział w rejsach wycieczkowych na świecie), to średnie obłożenie statków wycieczkowych wynosi prawie 100\%. Co więcej, morskie rejsy turystyczne są segmentem turystyki o największym względnym wzroście liczby turystów. Największą rolę w turystyce morskiej odgrywają Morze Karaibskie wraz z Zatoką Meksykańską, a następnie Morze Śródziemne z przyległymi akwenami.

W Polsce, turystykę morską trudno jeszcze określić jako masową, ale niewątpliwie należy ona do szybko rozwijającego się segmentu rynku, stąd jest $\mathrm{w}$ ofercie niektórych touroperatorów. Grupa Atlas Tours, poza samolotami czarterowymi, wymienia luksusowe statki morskie, będące w istocie samowystarczalnymi mega-centrami wypoczynkowymi. Jeśli chodzi o rejsy luksusowymi statkami, Atlas Tours oferuje pomoc w organizacji wyjazdów indywidualnych i grupowych, w tym integracyjnych (ang. team building), a także sprzedaż całego pakietu obejmującego rejs statkiem i dojazdy do/z portu zaokrętowania autokarem lub samolotem. Touroperator współpracuje z liniami rejsowymi, takimi jak MSC Cruises, Norwegian Cruise Line, Royal Caribbean International, Costa Cruises. Rejsy dla grup organizowane przez MSC Cruises odbywają się w kilku rejonach, przede wszystkim w basenie Morza Śródziemnego i Czarnego, Morza Bałtyckiego i do krajów skandynawskich. Norwegian Cruise Line pływa wokół Ameryki Północnej (Alaska, Kanada, Lodowiec Sawyer), Środkowej i Południowej (Kolumbia, Kostaryka, Meksyk, Wyspy Dziewicze, Aruba, Curacao), Royal Caribbean International - po wodach Ameryki Środkowej (Haiti, Jamajka, Meksyk). Costa Cruises odbywa rejsy po Azji Wschodniej (z Szanghaju do Singapuru przez Okinawę, Hong-Kong, Sanya, Da Nang). Zwykle rejs trwa od kilku do kilkunastu dni. Na krótszych wycieczkach zazwyczaj dzień przeznaczony jest na indywidualne zwiedzanie miast portowych w porze popołudniowej, a nocą statki przemieszczają się do kolejnego portu. W przypadku dłuższych wycieczek, rejs bez zawijania do portów zajmuje kilka dni. Oferta rejsów indywidualnych obejmuje tylko sprzedaż 
samego rejsu - głównie po Morzu Środziemnym i w Europie Północnej, rzadziej w obszarach egzotycznych jak Hawaje, Floryda, Bahamy, czy Karaiby.

Sigma Travel, poza samolotami rejsowymi i autokarami, podaje promy morskie jako wykorzystywane środki transportu, przede wszystkim w celu transferów między miejscowościami. Touroperator korzysta z promów w trakcie realizacji wycieczek wielodniowych, np. w relacjach Macau-Hong-Kong, na wyspę Miyama w Japonii (powrót koleją gondolową), na wyspę Bali, na brytyjską wyspę Skye, po Jeziorze Bodeńskim, w trakcie przemieszczeń z Europy do Maroka, po Bałtyku (na trasie Gdańsk-Nynashamn, Rostock-Gedser), po Eisfiord. Część połączeń ma charakter dalekosiężnego transferu, niektóre są lokalne. Touroperator z reguły wykorzystuje rozkładowe połączenia promowe.

Regularne promy w dużej mierze wykorzystuje także Itaka, m.in. podczas wycieczek autokarowych. Przykładem moga być rejsy z Tallina do Helsinek, w archipelagu Wysp Kanaryjskich, na wybrzeżu Chorwacji. Promy są też wykorzystywane do krótkich wyjazdów z miasta noclegu (np. we Włoszech na pobliskie wyspy) lub w trakcie wycieczek fakultatywnych.

Również Rainbow Tours ma w swojej ofercie promy i statki wycieczkowe jako środki transportu. Wykorzystywane promy odbywaja regularne rejsy po Bałtyku, na trasach: Świnoujście-Ystad (armator Unity Line), Oslo-Kopenhaga (DFDS) i Turku-Sztokholm. Na tej ostatniej trasie pływa największy prom wycieczkowy Silja Europa należący do armatora Tallink. Na innych krótkich trasach (np. we Włoszech na pobliskie wyspy, na wyspę Skye, przez Kanał La Manche) wykorzystywane są lokalne promy, często bezkabinowe. Rainbow Tours korzysta także ze statków cypryjskiego armatora Louis Cruises do wykonywania czterodniowych rejsów „okrężnych” po portach greckich, rozpoczynających i kończących się w Pireusie.

TUI Poland ma w swojej ofercie wycieczki żaglowcami „Leonardo” i „Otac Nicola” (Chorwacja) oraz rejsy po Nilu, zazwyczaj statkiem wycieczkowym „Helio”. Ponadto klienci mogą korzystać z bogatej oferty TUI Deutschland, obejmującej zwiedzanie na pokładach luksusowych statków wycieczkowych, pływających m.in. po Morzu Śródziemnym, Karaibach, Hawajach, Wyspach Bahama, w Ameryce Południowej, Azji, Afryce, norweskich fiordach i stolicach bałtyckich.

\section{Koleje}

Współcześnie kolej, będąc jednocześnie atrakcją turystyczną, sama staje się dobrem turystycznym i głównym motywem podróży. Obecnie zarządy wielu linii kolejowych, współpracując z wybranymi touroperatorami, organizują wycieczki dla większych grup turystów. W Szwajcarii, Austrii, Niemczech, Wielkiej Brytanii, Irlandii, a nawet na Węgrzech kolej staje się produktem turystycznym. Sama podróż komfortowym pociągiem z szerokimi oknami, wyposażonym niekiedy w wagon restauracyjny z narodową kuchnią, jest jedną z największych atrakcji. Niektóre biura podróży organizują również kilkudniowe wycieczki kole- 
jowe w taki sposób, aby turyści mogli odwiedzić kilka krajów (Orient Express). Doskonałym przykładem wykorzystania linii kolejowych do uprawiania rozmaitych form turystyki jest Szwajcaria, gdzie w 2008 r. utworzono sieć turystyczną pn. SchweizMobil (Załuska, 2010), przeznaczoną do uprawiania turystyki grupowej i indywidualnej. Railtours Ireland w porozumieniu z Iarnród Éireann (Kolej Irlandzka) organizuje jedno- i kilkudniowe wycieczki objazdowe koleją i autokarem z Dublina do najbardziej atrakcyjnych części Zielonej Wyspy.

Mimo to kolej jest wykorzystywana jako środek transportu przez nielicznych naszych touroperatorów i to raczej za granicą niż w Polsce. Rozkładowe pociągi są na przykład w ofercie Itaki (TGV do przejazdu z Nicei do Cannes, Kolej Transsyberyjska od Irkucka do Listwinki, Shinkansen na trasie Fukuoka-Hiroshima). Wykorzystywane są również szybkie i klasyczne koleje w Chinach, a także zabytkowa kolej parowa w Indiach. Rainbow Tours, w przeprawach wycieczek autokarowych z kontynentu do Wielkiej Brytanii (obok promów) podaje pociągi jadące Eurotunelem. Nocne przejazdy rozkładowym pociągiem mają w swojej ofercie wycieczkowej na przykład Alfa Star (na trasie Asuan-Giza) i TUI (Asuan-Kair). Ten ostatni przejazd był również w ofercie upadłej Triady. W Chinach na trasie Pekin-X'ian nocny przejazd pociągiem jest w ofercie TUI.

Niektórzy touroperatorzy (np. TUI Poland), korzystający czasem z zagranicznych lotnisk umożliwiają swoim klientom bezpłatny bilet na dojazd pociągiem do dowolnego lotniska na terenie Niemiec w ramach usługi rail \& fly. Nie jest ważne skąd się wylatuje, ponieważ transport do portu lotniczego zaoferowany zostaje klientom bezpłatnie. Dotyczy to również dojazdu z dworca do lotniska. Dzieje się tak na podstawie umowy TUI z dyrekcją Deutsche Bundesbahn, dwunastoma lokalnymi przewoźnikami kolejowymi (m.in. Regional Bahn, Stadt Express, Regional Express, S-Bahn) oraz Związkiem Przewoźników Regionalnych VDV (U-Bahn, autobusy, tramwaje). Do dokumentów podróży, które klienci otrzymują od TUI, dołączone są bilety kolejowe ważne 48 godzin przed rozpoczęciem i 48 godzin po zakończeniu podróży. Takie rozwiązanie jest dogodne dla mieszkańców zachodniej Polski, którym bliżej jest do Berlina czy Drezna niż do Warszawy.

\section{Środki transportu niewykorzystywane przez badanych touroperatorów}

Kolej, poza pełnieniem funkcji użytkowej, czyli prowadzenia regularnego ruchu pociągów wykorzystywanych w turystyce, może pełnić rolę podstawowej lub uzupełniającej atrakcji turystycznej. W Polsce, mimo istnienia ogółem 37 kolei turystycznych, w tym 28 podmiotów prowadzących ruch pociągów na liniach wąskotorowych, turystyka kolejowa jest jeszcze stosunkowo nowym zjawiskiem i dlatego mało popularna (Bebenow, 2015). Ogromną rolę w jej popularyzowaniu odgrywają kluby miłośników kolei (ang. railway enthusiasts, railway fans, niem. Eisenbahnfreunde), organizujące liczne imprezy i zlo- 
ty, a przede wszystkim rewitalizujące dawne trasy kolejowe. Potencjał turystyczny polskich kolei regionalnych nie jest jednak wykorzystywany ${ }^{2}$, mimo istnienia rozmaitych projektów ich wykorzystania w przewozach turystycznych w różnych regionach: na Dolnym Śląsku, w Karpatach, w Wielkopolsce, na Pomorzu, Warmii i Mazurach, w woj. łódzkim i śląskim (Bebenow, 2015; Lewandowski, 2013), w Puszczy Białowieskiej (Załuska, 2010). Najpowszechniej występującą formą odpowiedzi na potrzeby turystów jest udostępnianie zabytkowych obiektów kolejowych (ang. heritage railways) zwiedzającym, natomiast wykorzystanie kolei jako środka transportu często wiąże się z koniecznością rewitalizacji linii.

Za granica, w miejscach destynacji jako lokalne środki transportu wykorzystywane są czasem „pociągi” lilipucie o napędzie elektrycznym (akumulatorowym). Przykładami są takie „pociągi” w krajach śródziemnomorskich, w Hiszpanii, we Włoszech, na północnym wybrzeżu Krety lub wzdłuż Jezior Plitwickich w Chorwacji. Pociągi lilipucie stają się coraz bardziej popularne również w Polsce (w miastach, w miejscowościach nadmorskich i górskich). Jednakże, informacje o takich miejscowych środkach transportu z reguły nie są podawane w ofercie touroperatorów.

\section{Wnioski}

Przeprowadzona analiza pozwoliła, między innymi, na wyprowadzenie poniższych uogólnienień i prawidłowości.

1. Zazwyczaj im obroty touroperatora są większe, tym większa jest liczba współpracujących przewoźników i różnorodność wykorzystywanych środków transportu. Najwięksi nasi touroperatorzy w zasadzie korzystają jednak wyłącznie z samolotów i/lub autokarów. Inne środki transportu, takie jak statki morskie, promy, czy kolej, wykorzystywane są sporadycznie lub wcale, mimo dużych potencjalnych możliwości ich wykorzystania w masowym zorganizowanym ruchu turystycznym.

2. W transporcie autokarowym można wyróżnić trzy rodzaje działalności: dowozy „antenowe” regularnymi liniami autokarowymi (czasem mikrobusami i samochodami osobowymi) uczestników wyjazdów z mniejszych miejscowości do hubów, przewozy małych grup rejsowymi autokarami i wykorzystywanie (niekiedy czarterowanie) całych autokarów przez touroperatora (również w miejscu destynacji).

3. Część badanych touroperatorów dysponuje własnym parkiem autokarowym (np. Jan Pol Incoming Tour Operator, Mazurkas Travel, Funclub, Atas, Skarpa

2 Tak jak w Niemczech, gdzie biura podróży jak IGE-Bahntouristik organizują wycieczki zabytkowym taborem (np. lokomotywami parowymi) po ogólnodostępnej infrastrukturze kolejowej. U nas, pociągi prowadzone rozkładowo przez parowozy pozostawiono tylko w parowozowni (lokomotywowni) Wolsztyn. 
Travel), którym realizuje przewozy klientów własnych i konkurencji. W przypadku grup przedsiębiorstw takich jak np. Almatur odnotowuje się wykorzystywanie przez touroperatorów nieposiadających własnego parku autokarów pojazdów innych podmiotów tej samej grupy. Własne środki transportu, o ile takie znajdują się w posiadaniu polskiego touroperatora, ograniczają się do floty autokarów, a nie do posiadania własnego przewoźnika lotniczego. To z kolei jest domeną większych touroperatorów z kapitałem obcym (TUI, Neckermann).

4. Touroperatorzy zajmujący się turystyką przyjazdową zazwyczaj dysponują własnym parkiem autokarowym (np. Jan Pol Incoming Tour Operator, Mazurkas Travel). Własna flota autokarów charakterystyczna jest głównie dla touroperatorów z wyłącznym kapitałem polskim. Najwięksi touroperatorzy z kapitałem obcym i mieszanym polsko-zagranicznym z reguły nie posiadają własnego parku autokarowego.

5. Brakuje precyzyjnych informacji na temat współpracy polskich touroperatorów z konkretnymi przewoźnikami autobusowymi. Tylko kilku touroperatorów podaje takie informacje na swoich stronach internetowych. Może to wskazywać na brak długoterminowych porozumień o współpracy i dobieraniu przewoźników na bieżąco, w zależności od potrzeb.

6. Część przewoźników autokarowych świadczących usługi na rzecz największych polskich touroperatorów (np. Żak Express, Hubertus) wykonuje także usługi turystyczne pod własnym szyldem, zarówno pośrednicząc w sprzedaży cudzych imprez, jak i organizując własne (np. wycieczki szkolne, zakładowe).

7. Charakterystyczną cechą analizowanych przewoźników autokarowych jest własność osób fizycznych w postaci bądź jednoosobowej działalności gospodarczej, bądź też spółek cywilnych lub jawnych. Jednakże, nawet firmy o kapitale pochodzącym od osób fizycznych, dysponują stosunkowo rozbudowanym parkiem pojazdów.

8. Większość badanych przewoźników autokarowych ma swoje siedziby w południowej Polsce. W przypadku touroperatorów krakowskich obserwuje się wykorzystywanie autokarów miejscowych przewoźników.

9. Autokary wykorzystywane są przede wszystkim w bliższych relacjach, szczególnie przy wyjazdach narciarskich (Alpy, Dolomity), a częściowo podczas wycieczek objazdowych (np. po Europie Środkowo-Wschodniej, Europie Południowej).

10. Pozostałe środki transportu wykorzystywane są przez największych, analizowanych touroperatorów sporadycznie i wtedy raczej nie są ich własnością (tak jak statki wycieczkowe, promy, koleje). Tylko niektórzy organizatorzy podróży informują o korzystaniu z innych niż samolot i/lub autokar środków transportu w masowych zorganizowanych imprezach turystycznych. 


\section{Piśmiennictwo / References}

Bebenow F., 2015, Turystyka kolejowa w Polsce, Studia i Prace z Geografii, 53, Bogucki Wydawnictwo Naukowe, Poznań.

Becken S., 2005, Towards sustainable tourism transport: An analysis of coach tourism in New Zealand, Tourism Geographies, 7, 1, s. 23-42.

Chiambaretto P., Decker Ch., 2012, Air-rail intermodal agreements: Balancing the competition and environmental effects, Journal of Air Transport Management, 23, s. 36-40.

Cornell J., 2008, World Cruising Routes, Adlard Coles Nautical, London, 6 wyd.

Dickinson B., Vladimir A., 2008, Selling the Sea. An Inside Look at the Cruise Industry, John Wiley \& Sons, Hoboken, NJ, 2 wyd.

Dickinson J.E., Robbins D., 2008, Representations of tourism transport problems in rural destination, Tourism Management, 29, 6, s. 1110-1121.

Dowling R.K. (red.), 2006, Cruise Ship Tourism, CABI, Wallingford-Cambridge, MA.

Gawek R., 2000, Kolejowe przewozy pasażerskie w gospodarce turystycznej, Problemy Turystyki, 23, 3-4, s. 19-33.

Givoni M., Banister D., 2006, Airline and railway integration, Transport Policy, 13, 5, s. 386-397.

Halsall D.A., 2001, Railway heritage and the tourist gaze: Stoomtram Hoorn-Medemblik, Journal of Transport Geography, 9, 2, s. 151-160.

Konieczna-Domańska A., 2008, Biura podróży na rynku turystycznym, Wydawnictwo Naukowe PWN, Warszawa, 2 wyd.

Lewandowski K., 2013, Turystyka kolejowa na Dolnym Śląsu, Przegląd Komunikacyjny, 12, s. 23-29.

Panasiuk A., Pluciński M. (red.), 2008, Transport lotniczy i morski w obstudze ruchu pasażerskiego. Implikacje dla regionów, Uniwersytet Szczeciński, Zeszyty Naukowe, 491, Szczecin.

Taylor Z., Ciechański A., 2014a, Transport Companies in the Servicing of Organised Tourism in Poland, Monographs IGiPZ PAN, 16, Warszawa.

Taylor Z., Ciechański A., 2014b, Obstuga zorganizowanego ruchu turystycznego w Polsce, Przegląd Geograficzny, 86, 4, s. 471-497.

Taylor Z., Ciechański A., 2015a, Transport lotniczy w obstudze polskich touroperatorów część I, Przegląd Geograficzny, 87, 2, s. 255-278.

Taylor Z., Ciechański A., 2015b, Transport lotniczy w obstudze polskich touroperatorów część II, Przegląd Geograficzny, 87, 4, s. 569-588.

www.infoveriti.pl - serwis InfoVeriti Polska udostępniający sprawozdania składane w Krajowym Rejestrze Sądowym (5.10.2013, 16.12.2013).

Załuska E., 2010, Turystyka kolejowa integratorem lokalnych inicjatyw, Transport i Komunikacja, 6, s. 72-74.

[Wpłynęło: maj 2015 r.] 


\section{ZBIGNIEW TAYLOR, ARIEL CIECHAŃSKI}

\section{COOPERATION OF TOUR OPERATORS WITH NON-AIR PASSENGER CARRIERS IN POLAND}

Alongside air transport, road transport plays an important role in the servicing of the mass organised tourist traffic in Poland. The purpose of this paper is therefore to present the major road carriers, including firms offering and providing feeder services, as well as transport at destinations. All other carriers facilitating tourism (cruise liners, ferries and railways) are also presented, though their role is found to be much smaller than that of their air and coach counterparts, where organised tourist traffic is concerned.

Coach is the second most-used means of transport among the tour operators researched. According to the authors' accounts, it is used by $15.79 \%$ of tour operators, with instances of tourism involving coaches accounting for 3.2\% of their total turnover, and with $8.62 \%$ of customers involved in these. The role of the coach among the means of transport used is actually greater, since this is the most frequent mode of travel besides aircraft, in a category called 'various means' of transport.

It was even more typical for coaches to be made use of in the 1990s, but with increased affluence in Polish society, and a partial change in the nature of foreign outward travel from touring excursions (sightseeing) to typical leisure (holiday) tours, the role played by coaches has been in gradual decline. The coach allows for the avoidance of problems with transfer, luggage, the arrangement of travel formalities, a knowledge of foreign languages, and so on. "Coach tours are in the main cheaper than air travel, and frequently also than rail tours. Because of these advantages, the coach is a means of transport particularly gladly chosen in certain segments of tourist demand" (KoniecznaDomańska, 2008, p. 61).

In coach transport, three types of activity can be distinguished: tourist travel on 'feeder' lines from smaller localities to hubs using scheduled coaches (sometimes microbuses and cars), carriage of small groups by scheduled coaches, and the usage (sometimes charter) of whole coaches by tour operators (also at destinations).

Some of the tour operators researched have their own coaches available (e.g. the Jan Pol Incoming Tour Operator, Mazurkas Travel, Funclub, Atas and Skarpa Travel). These are put to use in both own carriage and that of the competition. In the case of groups of companies such as Almatur, tour operators not having their own stock use coaches of other members of their group. Own means of transport, if they are available, are limited to coaches only, and not air carriers. The latter, in turn, is a domain of larger tour operators with foreign capital (like TUI and Neckermann).

Tour operators involved in inward tourism usually have their own fleet of coaches (e.g. the Jan Pol Incoming Tour Operator and Mazurkas Travel). Possession of an own fleet of coaches is characteristic for tour operators with exclusively Polish capital. The largest tour operators with foreign and 'mixed' Polish-foreign capital as a rule do not own coaches.

There is no precise information available on cooperation between the Polish tour operators and individual coach carriers. Only a few tour operators provide such infor- 
mation on their websites. This may point to a lack of long-term cooperation agreements, with carriers being chosen ad hoc, in line with the needs of the given time.

Some coach carriers (e.g. Żak Express and Hubertus) rendering services for the largest Polish tour operators, also engage in tourist services under their own brand name, selling someone's else events, or organising their own instances of tourism (e.g. school excursions, works' outings and trips). It is of interest that a majority of the coach carriers analysed have their seats in southern Poland. In the case of the Cracow-based tour operators, it is possible to note the use of local coach carriers.

The remaining means of transport are used only occasionally by the largest tour operators. Only some of these provide information on the usage of other means of transport besides aeroplanes and/or coaches during organised instances of tourism.

In Poland, maritime tourism cannot be qualified by the adjective 'mass', though it is a fast-developing segment of the market, and certain offers are to be found amongst selected tour operators (such as Atlas Tours, Sigma Travel, Itaka, Rainbow Tours, TUI Poland). It is usual for tour operators to cooperate with cruise ships and/or ferries on various seas, rivers or lakes.

Railways are also only seldom used as means of transport by our tour operators, and rather abroad than in Poland. Scheduled trains feature in the offer from Itaka, Rainbow Tours, Alfa Star and TUI. Moreover, some tour operators (e.g. TUI Poland) that make use of foreign airports provide their customers with free tickets for rail access to any airport in Germany, in the context of a service called rail\&fly. This is also true of the transfer from railway station to airport.

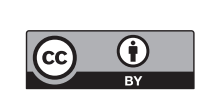


http://rcin.org.pl 